fourth study years were statistically significant differences detected between treatments. The pattern of significance was not consistently related to cutoff duration during those years. Soluble solids influence the fresh-todry fruit weight ratio (table 3 ). Higher soluble solids with early cutoffs tended to be reflected in lower dry ratios.

\section{Summary}

Both leaf water potential and stomatal conductance were reduced in relation to the duration of water deprivation before harvest. After 4 years, irrigation cutoff regimes ranging from 45 to 12 days prior to harvest had no significant effect on the cumulative amount or timing of preharvest fruit drop. Only in the fourth year were fruit load and dry yield reduced, and then only for the longest cutoff regime (45 days). This result was attributed to reduced vegetative growth limiting the number of fruiting positions. The next most severe cutoff regime ( 37 days) produced generally higher fruit loads, presumably due to increased flowering. Dried fruit size was not consistently affected by the cutoff duration. Soluble solids tended to be higher and dry ratios lower with early cutoffs.

Based on this study, we conclude that prune trees growing in deep, well-drained soils can tolerate moderate to severe water stress (equivalent to a maximum of about 7 acre-inches / acre less ETc) for several weeks prior to harvest without major yield or quality losses. In shallow soils with smaller soil moisture reservoirs, more rapid development and magnitudes of tree water stress are likely, shortening the safe duration of preharvest water deprivation.

D. A. Goldhamer is Water Management Specialist, Department of Land, Air, and Water Resources, UC Davis, located at the Kearney Agricultural Center, Parlier; G. S. Sibbett is Farm Advisor, Tulare County Cooperative Extension, Yisalia; $R$. C. Phene and D. G. Katayama are former Staff Research Associates at the Kearney Agricultural Center.

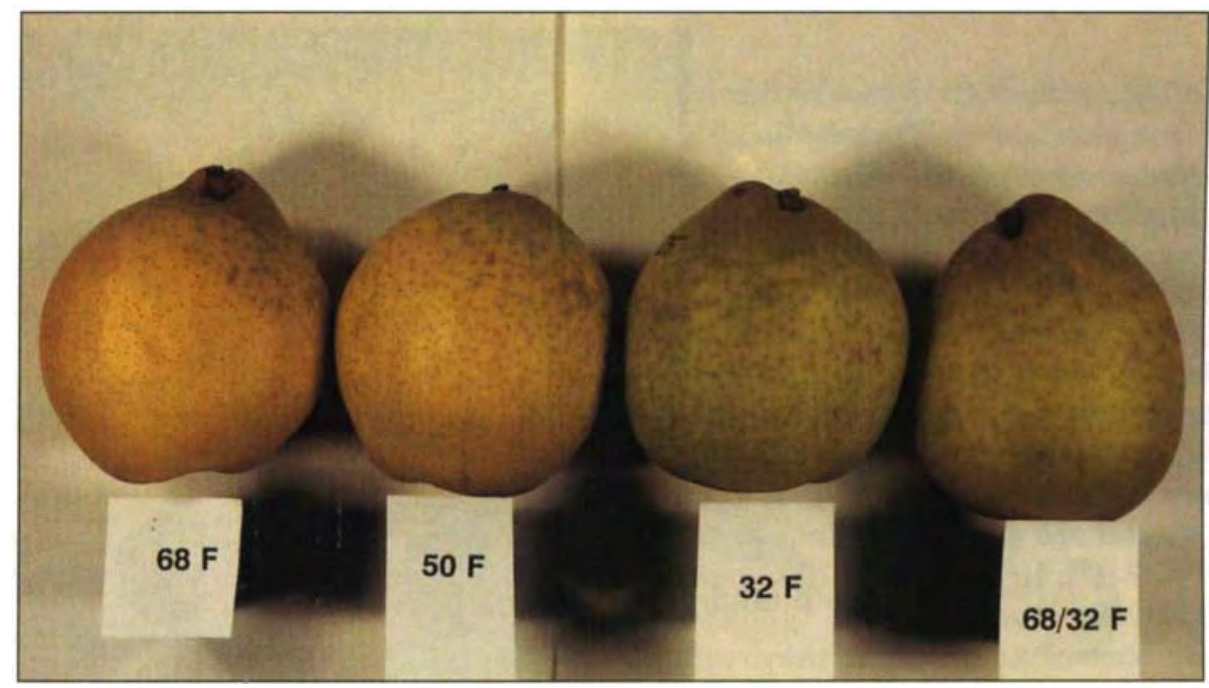

Skin color of 'Ya Li' turned to bright yellow after one month of storage at $20^{\circ} \mathrm{C}\left(68^{\circ} \mathrm{F}\right)$ and to light yellow after one month of storage at $10^{\circ} \mathrm{C}\left(50^{\circ} \mathrm{F}\right)$.

\title{
Early harvest prevents internal browning in Asian pears
}

\author{
Carlos H. Crisosto a David Garner a Gayle M. Crisosto \\ G. Steven Sibbett 口 Kevin R. Day
}

Brown discoloration of the core, carpels and flesh of ' $\mathrm{Ya} \mathrm{Li}$ ' and 'Seuri' Chinese pears during storage depends on harvest date, not storage temperature. In this trial, fruit harvested no later than 180 days after full bloom showed no signs of browning. Browning occurred only in fruit that had been harvested when skin color had already changed from green to light green-yellow. Thus, skin color can be used to determine harvest date to avoid internal browning.

The development during storage of brown to dark brown water-soaked areas in the core and flesh of ' $\mathrm{Ya} \mathrm{Li}^{\prime}$, 'Seuri', 'Tsu Li' and 'Shin Li' Chinese pears has been reported in different growing areas in the United States. These symptoms appear in the core and flesh, but there is no external indication of their presence. It is unknown whether browning of the core and browning of the flesh are induced by the same conditions, but both limit the opportunity to store and market Chinese pears.

The cause of internal browning (IB) in Chinese pears is not known, and no information about its control is available. In this study, we evaluated the effects of harvest date and storage temperature on internal browning and other aspects of fruit quality for ' $\mathrm{Ya} \mathrm{Li}$ ' and 'Seuri' Chinese pears.

During the 1992 season, fruit samples of 'Ya Li' and 'Seuri' pears growing in the Kingsburg area of Kings County were collected periodically, beginning 10 days before and extending 10 days after commercial harvest, in order to obtain samples with a range of green to yellow skin color. The samples were collected from five randomly selected healthy and mature trees, each of which served as a replicate.

At harvest, the fruit quality was evaluated by measuring skin color (with a Minolta chromometer), flesh firmness (with a penetrometer equipped with a 12-mm tip), soluble solids content (SSC) with a refractometer, and the incidence of IB. 
Then 25 fruit from each of the five replications per harvest date were volume-packed in corrugated boxes without liners and stored at $90 \%$ relative humidity and at $0^{\circ} \mathrm{C}\left(32^{\circ} \mathrm{F}\right), 10^{\circ} \mathrm{C}\left(50^{\circ} \mathrm{F}\right)$ or $20^{\circ} \mathrm{C}\left(68^{\circ} \mathrm{F}\right)$. To measure water loss during storage, individual fruit from each treatment were labeled and weighed before being stored.

After one month of storage at $0^{\circ} \mathrm{C}\left(32^{\circ} \mathrm{F}\right), 10^{\circ} \mathrm{C}\left(50^{\circ} \mathrm{F}\right)$ or $20^{\circ} \mathrm{C}$ $\left(68^{\circ} \mathrm{F}\right)$, the fruit were remeasured for quality in the same manner as at harvest. Each fruit was also reweighed, and the percentage of weight loss during storage was calculated.

\section{Fruit quality at harvest}

The soluble solids content (SSC) of the 'Ya Li' and 'Seuri' Chinese pears was not increased by delaying harvest (fig. 1). However, a slow but constant decline in fruit firmness to about 10 pounds-force occurred in both cultivars over the harvesting period. Previous research indicates that mature Chinese pears, when properly thinned,

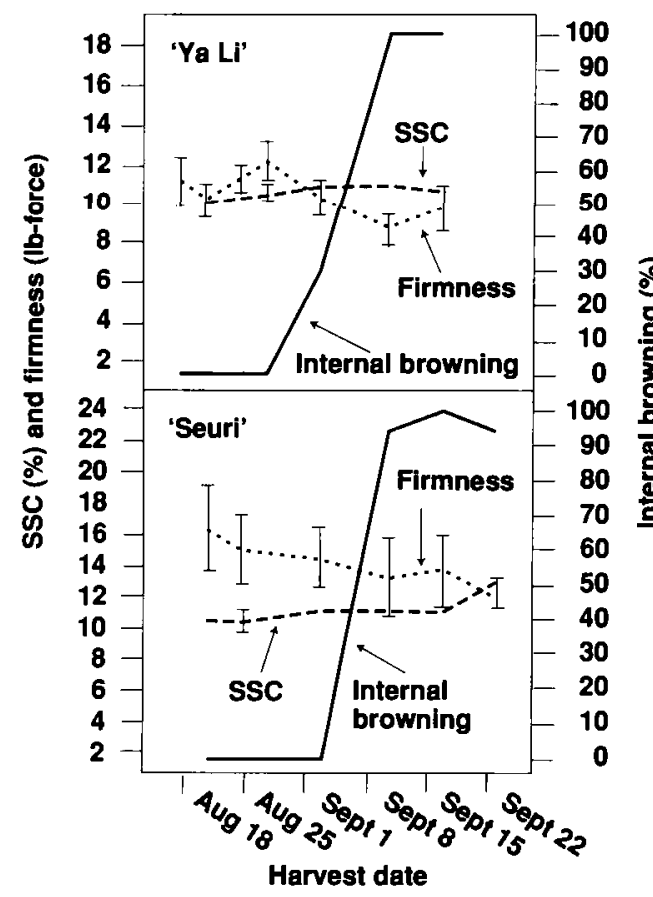

Fig. 1. Soluble solids content (SSC), firmness and internal browning incidence in ' $\mathrm{Ya} \mathrm{Li}$ ' and 'Seuri' Chinese pears after one month of storage at $0^{\circ} \mathrm{C}\left(32^{\circ} \mathrm{F}\right)$.

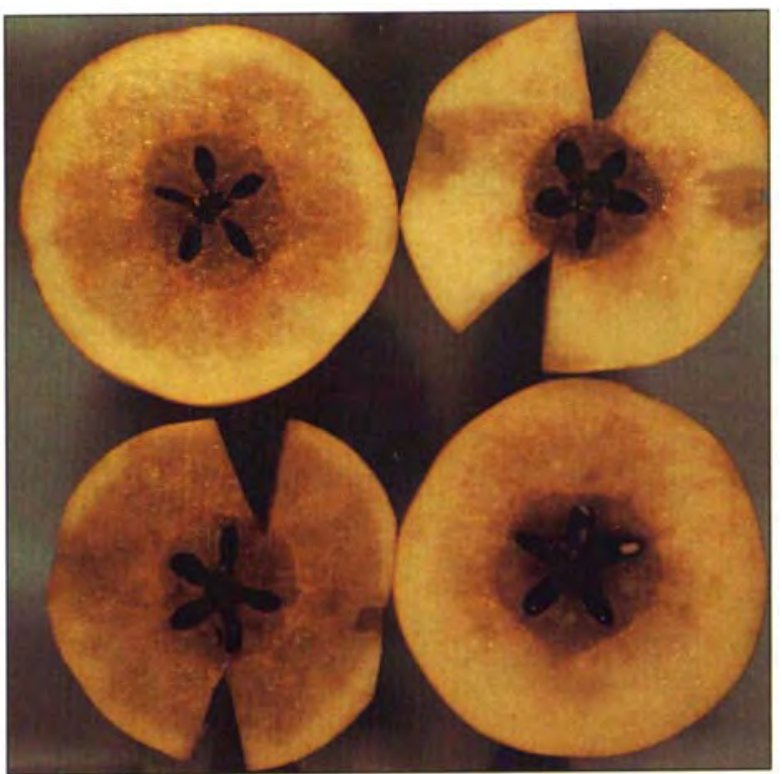

Core and flesh browning symptoms of ' $\mathrm{Ya} \mathrm{Li}$ pears.

should have a flesh firmness of 8 to 11 pounds-force and an SSC near $12.5 \%$. On each harvest date, fruit firmness was always higher for 'Seuri' than for 'Ya Li', but SSC did not differ significantly between the two cultivars.

The appearance of light yellow skin color was observed in 'Seuri' at the end of the harvest period. Partial disappearance of green skin color was detected after August 27 on ' $\mathrm{Ya} \mathrm{Li}$ ' and after September 3 on 'Seuri'. In both cultivars, disappearance of green color coincided with the appearance of a light green-yellow color.

\section{Storage performance}

Storage temperature had not influenced SSC in 'Ya Li' (table 1) or 'Seuri' (table 2) after one month in storage. However, the fruit firmness in both cultivars was affected by storage temperature and harvest date. The $20^{\circ} \mathrm{C}$ $\left(68^{\circ} \mathrm{F}\right)$ storage temperature generally resulted in lower fruit firmness than the $0^{\circ} \mathrm{C}\left(32^{\circ} \mathrm{F}\right)$ or $10^{\circ} \mathrm{C}\left(50^{\circ} \mathrm{F}\right)$ storage temperatures. Fruit harvested after September 3 and stored at any of the three temperatures had lower fruit firmness than fruit picked earlier in the season. Both cultivars had similar weight loss rates of $5 \%, 2 \%$ and $1.5 \%$ after the $20^{\circ} \mathrm{C}\left(68^{\circ} \mathrm{F}\right), 10^{\circ} \mathrm{C}\left(50^{\circ} \mathrm{F}\right)$ and $0^{\circ} \mathrm{C}\left(32^{\circ} \mathrm{F}\right)$ storage for one month, respectively.

Fruit stored at $20^{\circ} \mathrm{C}\left(68^{\circ} \mathrm{F}\right)$ or $10^{\circ} \mathrm{C}$ $\left(50^{\circ} \mathrm{F}\right)$ turned yellow during storage regardless of harvest date (tables 1 and 2). Generally, fruit color turned to a bright yellow after one month of storage at $20^{\circ} \mathrm{C}$ $\left(68^{\circ} \mathrm{F}\right)$ and to a light yellow after one month of storage at $10^{\circ} \mathrm{C}$ $\left(50^{\circ} \mathrm{F}\right)$. No visible color changes occurred during storage at $0^{\circ} \mathrm{C}$ $\left(32^{\circ} \mathrm{F}\right)$ on ' $\mathrm{Ya} \mathrm{Li}$ ' fruit picked before September 3 and 'Seuri' picked before September 11.

\section{Induced internal browning}

The incidence of browning in the core and flesh of both cultivars depended primarily on harvest date, except when fruit cooling was delayed. Internal browning was induced in ' $\mathrm{Ya} \mathrm{Li}^{\prime}$ picked after August 21 and 'Seuri' picked after September 3 by holding the fruit for one week at $20^{\circ} \mathrm{C}\left(68^{\circ} \mathrm{F}\right)$ before storing them at $0^{\circ} \mathrm{C}\left(32^{\circ} \mathrm{F}\right)$ for three weeks.

No core or flesh browning had been detected in any fruit samples examined at harvest. IB symptoms were found following a month of storage only in ' $\mathrm{Ya} \mathrm{Li}$ ' harvested after August 27 and in 'Seuri' harvested after September 3 (fig. 1). After one month of storage, $100 \%$ of both the ' $\mathrm{Ya} \mathrm{Li}^{\prime}$ and 'Seuri' fruit that had been harvested on September 11 showed IB symptoms. Browning was thus very affected by harvest date; it was not affected by storage temperature (tables 1 and 2).

IB symptoms included a brown discoloration of the core and carpel areas of the fruit and, in most cases, the brown core was accompanied by dark brown, water-soaked areas and /or translucent soft areas in the fruit flesh.

\section{Browning starts in core}

Fruit always had a higher incidence of browning in the core than in the flesh (data not presented). We never observed flesh browning without core browning, which suggests that the disorder begins in the core and then progresses to the flesh.

IB symptoms are similar to those of core breakdown reported in several European pear cultivars, such as 'Bartlett', 'Bosc', 'Comice' and 'Clapp Favorite'. More detailed work is 


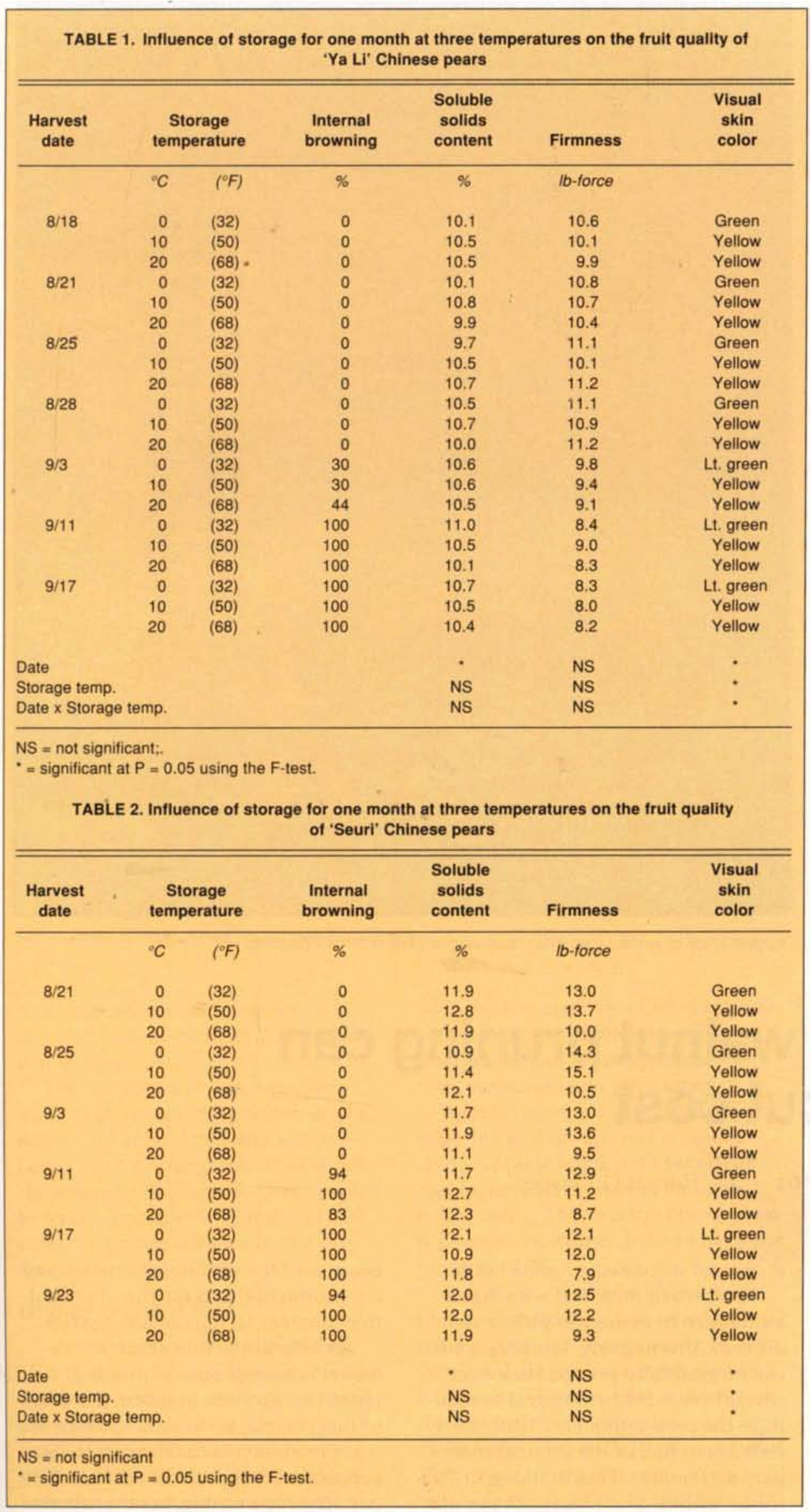

needed to identify which physiological changes during fruit maturation and senescence are causing this disorder.

In both cultivars, the occurrence of IB during storage was observed only on fruit harvested when their skin color had changed from green to light green-yellow. Thus, skin color changes during the harvest season may be useful in predicting IB incidence during storage of ' $\mathrm{Ya} \mathrm{Li}$ ' and 'Seuri' Chinese pears.

\section{Conclusions}

Browning in the core is an early stage of the dark brown discoloration of the flesh of ' $\mathrm{Ya} \mathrm{Li}$ ' and 'Seuri' Chinese pears. Both can be avoided by harvesting fruit earlier than the current commercial harvest dates in the San Joaquin Valley. In our trial, fruit picked later than 180 days after full bloom were affected by internal browning.

To avoid internal browning, fruit should be picked when most of the pears on the tree are still green and only a few exposed top fruit are beginning to show yellow spots. Green Chinese pears will turn light green or yellow during storage, depending on storage temperature, and will become bright yellow after one week of ripening at $20^{\circ} \mathrm{C}\left(68^{\circ} \mathrm{F}\right)$. Since the SSC did not increase in fruit picked late in the harvest period, there is no benefit in delaying harvest. Picking fruit when the skin is beginning to turn yellow will likely induce high IB incidence, especially if cooling is delayed. Fruit picked when the skin is completely yellow will develop IB within one month of harvest. We suggest growers keep records of the number of days after full bloom needed for their Chinese pears to turn yellow to help them schedule early harvests in subsequent years.

Carlos H. Crisosto is Postharvest Physiologist, David Garner and Gayle M. Crisosto are Staff Research Associates, all with the Department of Pomology, UC Davis, stationed at Kearney Agricultural Center, Parlier. G. Steven Sibbett and Kevin R. Day are Farm Advisors, Tulare County Cooperative Extension, Visalia. 